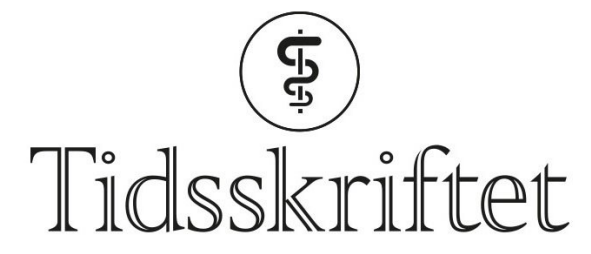

DEN NORSKE LEGEFORENING

\title{
To små planeter
}

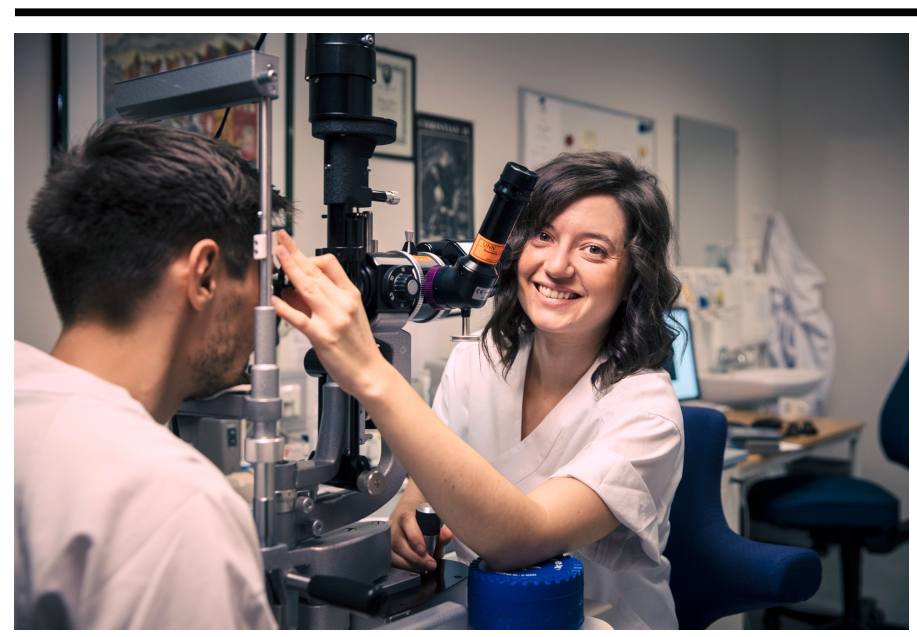

MITT FAGFELT

Emina Bektesevic Holmlund er lege i spesialisering i øyesykdommer ved Universitetssykehuset Nord-Norge.

- Fascinasjonen for oftalmologi startet kanskje da jeg som barn fikk mine første briller og verden med ett ble klarere. Mamma fortalte meg om brytningsfeil, og dette var antagelig en av de første tankene jeg gjorde meg om organfunksjoner. Min biologiinteresse vokste seg stadig større etter det, og oftalmologien var et favorittfag under medisinstudiet, forteller Bektesevic Holmlund.

Hun tok en kort omvei etter turnus og jobbet med generell kirurgi i to år, ettersom det virket fornuftig først å samle erfaring fra et større fag.

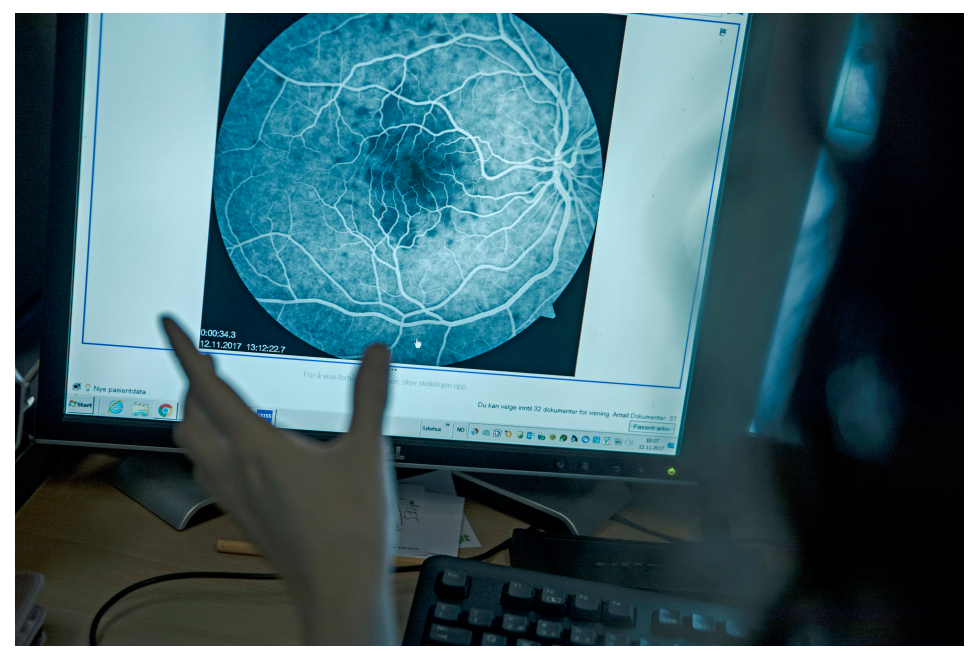

- Men å kalle oftalmologien et «småfag» føles dog misledende. Det er et stort fag som omfatter både rene øyesykdommer, indremedisin og kirurgi. Fordypning i øyefaget føles 
som fordypning i en egen medisinsk verden - jeg liker å omtale øynene som planeter i det biologiske universet. Øyet er et unikt organ i den forstand at man kan se rett inn i det og i de fleste tilfeller visuelt påvise sykdom. Diagnostikken er i stor grad avhengig av akkurat slike funn.

\section{Kan du fortelle om noe viktig som skjer i faget ditt for tiden?}

- Øyet, dette vidunderlige, lille organet, kan rammes av overraskende mange sykdommer, også kroniske, enten isolert eller som ledd i en systemsykdom. Oftalmologien er et svært objektivt, visuelt og teknisk fag, og automatiserte metoder kan bli et viktig verktøy innenfor fagfeltet. Studier har vist at bildeanalyser ved hjelp av maskinlæringsalgoritmer basert på kunstige nevrale nettverk har høy sensitivitet og spesifisitet for funn av diabetisk retinopati (1). Pasienter med diabetes utgjør en stor gruppe som trenger livslang oppfølging, og maskinlæring vil kunne tilby svært rask og nøyaktig diagnostikk.

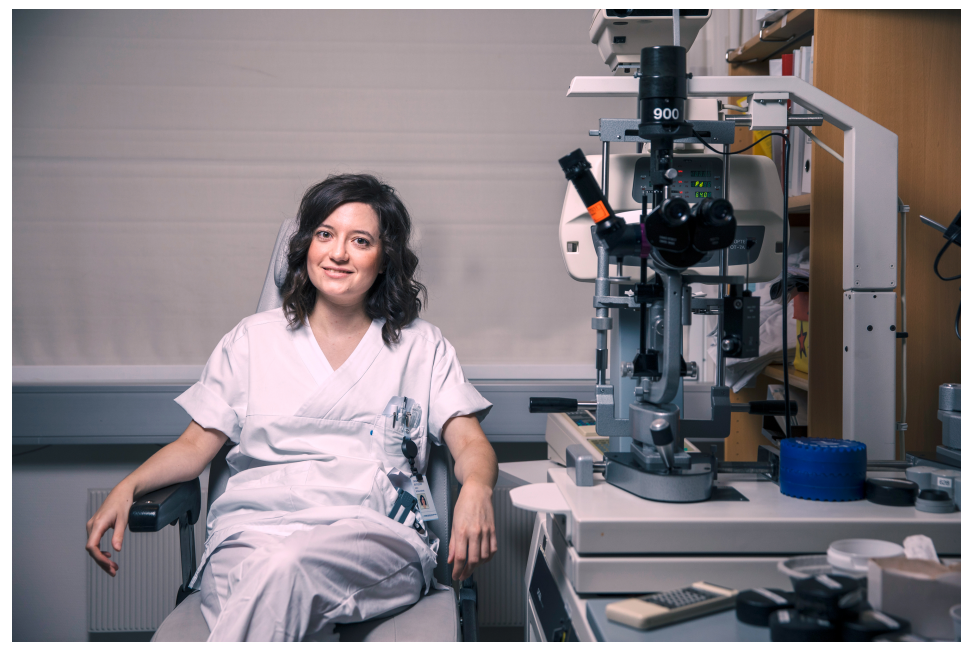

Alt tyder på at maskinlæring innenfor medisinen fungerer, og det er naturlig å tro at det $\mathrm{i}$ fremtiden kommer til å spille en stor rolle i et fag som oftalmologi. Man vil naturligvis trenge en lege som i samråd med pasienten tar medisinske beslutninger basert på de objektive funnene et maskinlæringsverktøy tilbyr, men man antar at nøyaktigheten av vurderingene vil øke takket være fremskritt innen bildeanalyser. De algoritmene som brukes, er for øvrig fascinerende like det oftalmologer interesserer seg for, nemlig synsbanene.

\section{Kan du anbefale en ny og interessant artikkel?}

- Myopi er en verdensomfattende epidemi, med svært høy forekomst i asiatiske land og stadig høyere forekomst i Europa. Dersom utviklingen fortsetter, antar man at halvparten av verdens befolkning vil være nærsynt innen 2050. Time spent in outdoor activities in relation to myopia prevention and control: a meta-analysis and systematic review er en metaanalyse av 25 artikler om dette temaet (2). Man har her sett på effekten av utendørsaktivitet og med det $\emptyset \mathrm{kt}$ bruk av avstandssyn på forebygging og begrensing av myopi, hovedsakelig hos barn. 


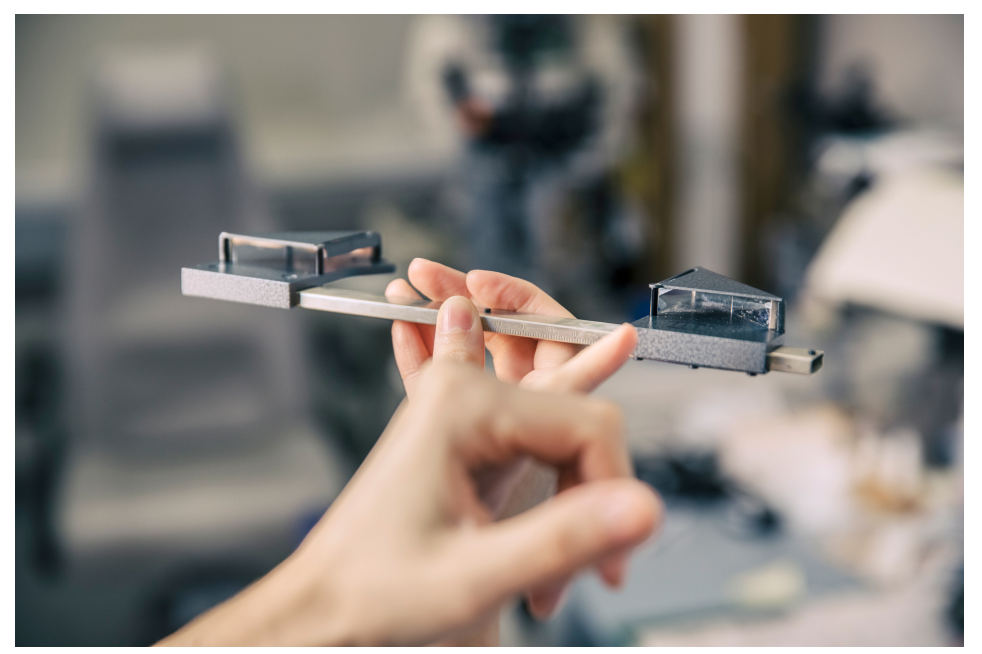

Det har lenge eksistert en teori, også langt utenfor fagmiljøet, om at nærarbeid øker risikoen for myopi, noe som igjen kan føre til mer alvorlig øyesykdom på sikt. Derfor er det faglig tilfredsstillende at antagelser tas til et høyere nivå og testes på en objektiv måte, der myter kan bekreftes eller avkreftes. Kort fortalt fant man i dette tilfellet at $ø$ kt utendørsaktivitet kan være en forebyggende faktor mot utvikling av myopi hos ikke-myope, men at det ikke hadde hemmende effekt på progredieringen hos dem som allerede hadde fått påvist myopi.

\section{Hva er ditt favoritthjelpemiddel på jobb?}

- Sesyn.no! Det er en elektronisk versjon av Ullevåls Metodebok for øyesykdommer. Den er gratis for all øyehelsepersonell, uavhengig av arbeidsgiver. Innholdet oppdateres regelmessig og er svært oversiktlig. Nettsiden fungerer bra på mobiltelefon, men det kunne muligens vært enda bedre om innholdet hadde vært tilgjengelig i en tilpasset mobilapplikasjon. Jeg håper de flinke kollegene som står bak både metodeboken og sesyn.no får mulighet til å utvikle dette videre!

\section{LITTERATUR:}

1. Gulshan V, Peng L, Coram M et al. Development and Validation of a Deep Learning Algorithm for Detection of Diabetic Retinopathy in Retinal Fundus Photographs. JAMA 2016; 316: 2402 - 10. [PubMed][CrossRef]

2. Xiong S, Sankaridurg P, Naduvilath T et al. Time spent in outdoor activities in relation to myopia prevention and control: a meta-analysis and systematic review. Acta Ophthalmol 2017; 95: 551- 66. [PubMed][CrossRef]

Publisert: 12. desember 2017. Tidsskr Nor Legeforen. DOI: 10.4045/tidsskr.17.0956 (C) Tidsskrift for Den norske legeforening 2020. Lastet ned fra tidsskriftet.no 